\title{
SEROPREVALENCE AND CLINICAL CORRELATES OF HUMAN IMMUNE DEFICIENCY VIRUS INFECTION AMONG CLIENTS WITH INFERTILITY IN NORTHWEST NIGERIA
}

\author{
ANISA YAHYA, ADEBIYI GBADEBO ADESIYUN \\ DEPARTMENT OF OBSTETRICS AND GYNAECOLOGY, \\ AHMADU BELLO UNIVERSITY TEACHING HOSPITAL, ZARIA NIGERIA
}

\section{PROBLEM STATEMENT:}

In Africa infertility prevalence is high and it is associated with major psychosocial burden.

HIV infection rate is also high in Africa and studies have shown that fertility may actually be reduced in infected women.

This association increases the social and psychological disturbance among a group of people that are already burdened with the HIV disease.

OBJECTIVE: The study determined the prevalence and clinical correlates of HIV infection among clients with infertility .

METHODOLOGY: A cross-sectional study conducted in women attending the infertility clinic at Ahmadu Bello University Teaching Hospital, Zaria

\section{RESULTS :}

Twenty one of the 250 clients tested positive for HIV giving a prevalence of $8.4 \%$. $33.3 \%$ were newly diagnosed HIV cases. $66.7 \%$ were known cases on antiretroviral therapy. Secondary infertility accounted for $81 \%$. Sociodemographic profile of HIV infected women with infertility was similar to that of other infertility patient. Majority of the human immunodeficiency virus positive clients $(66.7 \%)$ had no surviving child. History of multiple sex partners was positive among $85.7 \%$ of human immunodeficiency virus positive clients and $76.2 \%$ had never used condom in the past.

History of reproductive tract infection apart from human immunodeficiency virus infection among clients and their partners was high $(71.4 \%)$. History of blood transfusion was present in $33.3 \%$ of the human immunodeficiency virus positive clients and $4.8 \%$ of their partners respectively. Serodiscordance was seen in $42.9 \%$ of HIV positive women, $52.4 \%$ had stage II HIV disease., Tubo-peritoneal infertility was the commonest cause of infertility diagnosed in $71.4 \%$ of cases which showed a statistically significant association ( $p$ value 0.048 ). None of the other causes of infertility was statistically associated with HIV this study recorded a higher rate.

There is need to screen all clients with infertility and their partners for HIV infection.

There is also need for further research to understand the association between HIV infection and tuboperitoneal infertilityl infection. Polycystic ovarian syndrome was seen $14.2 \%$ of the clients. $4.8 \%$ of the clients were reported to have Hyperprolactinemia as a cause of infertility. Uterine factor and male factor infertility were each seen in $9.5 \%$ of the clients. $9.5 \%$ had multi factorial causes of infertility. 